\title{
Study of Antioxidant Potential of Tropical Fruit
}

\author{
Muhammad Aqeel Ashraf ${ }^{1}$, Mohd. Jamil Maah ${ }^{1}$, Ismail Yusoff ${ }^{2}$, Karamat Mahmood ${ }^{3}$, Abdul Wajid ${ }^{3}$
}

\begin{abstract}
This research work was carried out to quantify the total phenolics, flavonoids and carotenoides, vitamin $\mathrm{C}$ contents, reported as antioxidants, in the extracts of four locally available varieties of durian. Fruit was extracted using dichloromethane: pentane $(1: 1 \mathrm{v} / \mathrm{v})$ and subjected to study the various quality parameters. The total phenolic contents from durian fruit extract, determined following the Folin-ciocalteu assay were found in the range of $690.62-998.29 \mathrm{mg} / \mathrm{L}$, showing the significant inter-varietals variations. The total flavonoids and vitamin $C$ contents from fruit extract were found in the range of $211.36-220.34$ and $18.87-25.1 \mathrm{mg} / \mathrm{L}$, respectively. Whereas, the total carotenoides contents of fruit extract were found in a low concentrations i.e. $0.05-0.08 \mathrm{mg} / \mathrm{L}$. The statistical analysis showed significant $(p<0.05)$ variations in the total phenolic, carotenoides and vitamin $C$ contents while non-significant $(p>0.05)$ variation in total flavonoids contents among different varieties of durian. Caffeic acid and quercetin were the dominant antioxidant substances found in durian. In conclusion, the bioactivity of ripe durian was high and the total polyphenols were the main contributors to the overall antioxidant capacity.
\end{abstract}

Index Terms - Extract, Total phenolics, Flavonoids, Vitamin C, Carotenoides Ripe, Bioactive compounds; Antioxidant capacity and Phytochemicals

\section{INTRODUCTION}

Durian (Durio zibethinus Murray) is a fruit unique to Southeast Asia. It belongs to the family Bombacaceae in the order Malvales ooriginating in the Malay Peninsula [1].This is sort-of strange, as almost any fruit or vegetable with a somewhat appealing taste has long become a universally cultivated crop. Durian grows well in humid conditions (75$80 \%$ humidity) with a rain fall between 1,600 and 4,000 ml a year, and average temperature between 24 and $30^{\circ} \mathrm{c}$. Durian prefers a loamy soil type with a $\mathrm{pH}$ between 5.0 and 6.5. It requires a tropical climate and will not grow well in areas over 3000 feet altitude [2]. There are about 200 different varieties of durian in Malaysia, but only few varieties are favored and grown commercially.

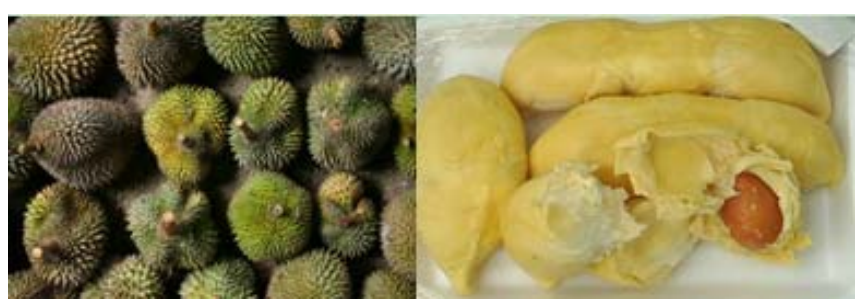

The four studied varieties are;

1) D11

2) Chaer Phoy (Green Skin Durian)

3) Yah Kang (Centipede Durian)

4) Ang Jin (Red Yoke Durian)
Most of the photochemicals are an integral part of the durian fruit and also being used in medicinal formulations. A number of health protective effects of phenolic compounds have been reported due to their antioxidant, antimutagenic, anticarcinogenic, anti-inflammatory, antimicrobial, and other biological possessions [3-5]. Currently durian fruit is popular in daily utilization because of their first-class flavor and health-promoting compounds, such as flavonoids, phenolics and carotenoides conents [610]. Phenolic compounds constitute one of the most plentiful and extensively distributed groups of substances in the plant kingdom and foods and fruit juices may have a very complex phenolic composition These are biogenetically arise secondary metabolic products of plants and their activity is reported due to the Polyphenols which demonstrate antibacterial, anti-inflammatory and vasodilatory actions that might be attributed to polyphenol compounds with antioxidant activity [11]

Dietetic carotenoid antioxidants from fruits and vegetables have been reported to play a vital role in human health and particularly, their inference in cancer prevention has grown a very immense interest in the antioxidant composition of fruits and vegetables. The carotenoides content of different fruit products like juices, provide a very useful clue about the quality of product [12-13].

Durian fruit contain a considerable amount of phenolics, flavonoids and carotenoids and their quantitative fingerprint shows differences in the proportions because of various locations of origins, agro-climatic conditions and dreadful diversity in species. The importance of this fruit is mostly connected with its composition and antioxidant properties [14-16]. It has been reported that durian has additional valuable health properties: polysaccharide gel, extracted from the fruit hulls, reacts on immune responses and is responsible for cholesterol reduction [17]. The glycaemic index of durian was the lowest in comparison with papaya and pineapple [18]. The heath properties of durian are based not only on the antioxidant properties, but also on its fatty acid composition. Cholesterol hypothesis implied that reducing the intake of saturated fats and cholesterol while increasing that of polyunsaturated oils is effective in lowering serum cholesterol, and thereby in reducing coronary heart disease. The protective activity is linked with a high supply of $n-3$ fatty acids coming from fish and seafood, and high consumption of wholegrain products, as well as fruits and vegetables [19]. Durian is rich in $n-3$ fatty acids, compared to some other fruits [20].

Although literature is available with major focus on the polyphenolic and carotenoid contents of durian fruit but such type of investigations are lacking regarding the intervarietal variations of these phytochemicals in durian fruit extract indigenous to Malaysia. The main objective of 
this work was to determine the total phenolics, flavonoids and carotenoid contents and amount of vitamin $C$ in various varieties of durian using spectrophotometric methods.

\section{MATERIAL AND METHODS}

\section{A. Collection of Samples}

All durian samples were harvested in June, 2010, from south and southwest hilly regions of Penang Island, from a 18 year old Bao Sheng Durian Farm at Titi Kerawang, near Pantai Aceh in Penang. The maturity of the durian fruits was determined by combined techniques: day count, character of fruit spines, tapping the fruit, colour and shape of the fruit [21]. Fresh ripened durian fruit samples (12 each) of four indigenous varieties of durian fruit (D11, Chaer Phoy, Yah Kang, Ang Jin) were procured from the Bao Sheng Durian Farm and transferred to research laboratory of Department of Chemistry, University of Malaya, Kuala Lumpur. Durian fruit samples were identified and authenticated by the kind assistance of botanist from the department. Fruits were cleaned and the edible parts were separated from seeds.

\section{B. Chemicals and Reagents}

Folin-Ciocalteu's phenol regent, 2, 2-Diphenyl-1picrylhydrazyl (DPPH), linoleic acid, butylated hydroxytoluene (BHT), $\beta$-carotene and Tween 40 were obtained from Sigma Chemical Co. (St. Louis, MO, USA). All the other chemicals/reagents and solvents used in this study were purchased from Merck (Darmstadt, Germany), unless stated otherwise.

\section{Extraction of Samples}

Fruit samples were mixed with dichloromethane: pentane $(1: 1 \mathrm{v} / \mathrm{v})[22]$ in a $1: 2$ proportion $(1 \mathrm{~kg}: 2 \mathrm{~L}$ solvent mix $)$ for $48 \mathrm{~h}$ at $4{ }^{\circ} \mathrm{C}$. The clear liquid was decanted and the solvent was evaporated under vacuum $(27.5 \pm 2.5$ in $\mathrm{Hg})$ at $50{ }^{\circ} \mathrm{C}$ and $50 \mathrm{rpm}$ in an RE52 Rotavaporator set-up (Yamamoto, Tokyo, Japan). The fruit extract $(1.7 \mathrm{ml} / \mathrm{kg}$ pulp) was sealed in a glass container and kept at $-20{ }^{\circ} \mathrm{C}$.

\section{Evaluation of Extract Quality}

The quality of extracted lequid of each variety was assessed by studying the various quality parameters like $\mathrm{pH}$, total dissolved solids, viscosity, density and acidity. For $\mathrm{pH}$ determination, $10 \mathrm{~g}$ of extract of each sample, blended with $20 \mathrm{~mL}$ deionized water was heated to $100{ }^{\circ} \mathrm{C}$ and then cooled to $25^{\circ} \mathrm{C}$ followed by the addition of $20 \mathrm{~mL}$ deionized water. The $\mathrm{pH}$ was measured at $25^{\circ} \mathrm{C}$ with a $\mathrm{pH}$ meter (Inolab pH 720, wtw 82362, Weiheim, Germany) [23]. The acidity of samples was determined according to the method reported by Morneo [24]. Each sample was titrated with 0.1 $\mathrm{M} \mathrm{NaOH}$ to $\mathrm{pH} 8.1$ monitoring with an electrode $\mathrm{pH}$ meter (Inolab pH 720, wtw 82362, Weiheim, Germany) at both 20 ${ }^{0} \mathrm{C}$ and $32{ }^{0} \mathrm{C}$ temperatures. Results were expressed as grams of citric acid per liter of sample solution. Total solids were measured following the official method of AOAC [23]. Briefly; after heating $5 \mathrm{ml}$ of sample juice in china dish in electric oven at $105{ }^{\circ} \mathrm{C}$ to a constant weight. Results were expressed as grams of total solids per liter juice. Viscosity of each sample was measured by viscometer and results were expressed as centipoises $(\mathrm{cP})$. density $\left(\mathrm{g} / \mathrm{cm}^{3}\right)$ of each sample was measured by specific gravity bottle at $25^{\circ} \mathrm{C}$.

\section{E. Determination of Total Phenolic Contents}

Total phenolic contents (TPC) were determined by following the Folin-Ciocalteu method [25-27] with slight modifications. Briefly, $1 \mathrm{~mL}$ of citrus juice was extracted with $9 \mathrm{~mL}$ of $80 \%$ methanol for $30 \mathrm{~min}$ at room temperature. After centrifugation $4000 \mathrm{rpm}$ for $10 \mathrm{~min}$, an aliquot $(1 \mathrm{~mL})$ of appropriately diluted $80 \%$ methanol extracts were added to a $25 \mathrm{~mL}$ volumetric flask filled with $9 \mathrm{ml}$ distilled water. Folin-Ciocalteu phenol reagent $(0.5 \mathrm{~mL})$ was added to the mixture and shaken vigorously. After $5 \mathrm{~min}, 5 \mathrm{ml}$ of $\mathrm{Na}_{2} \mathrm{CO}_{3}$ solution was added with mixing. The solution was immediately diluted to $25 \mathrm{ml}$ with distilled water and mixed thoroughly and then allowed to stand for $60 \mathrm{~min}$ before measurement, and the absorbance was measured at $750 \mathrm{~nm}$ versus the prepared blank. Quantification was done on the basis of a standard curve with gallic acid. Results were expressed as gram of gallic acid equivalents (GAE) per 100 g dry weight [28-30] (Figure 1a).

\section{F. Determination of Total Flavonoid Contents}

Total flavonoid contents (TFC) were determined by following the method of sultana [31] with slight modifications. In brief, $2.5 \mathrm{~g}$ of sample placed in a Soxlet extractor and refluxed with methanol for more then $2 \mathrm{~h}$ at 80 ${ }^{\circ} \mathrm{C}$. The extract was evaporated to dryness in a rotary vacuum evaporated at less than $40{ }^{\circ} \mathrm{C}$ and dissolved with methanol. Exactly $0.3 \mathrm{ml}$ of $5 \% \mathrm{NaNO}_{2}$ was added to $1 \mathrm{ml}$ of extract in a $10 \mathrm{~mL}$ volumetric flask and the mixture was kept for $10 \mathrm{~min}$ at room temperature. Addition $0 \mathrm{f} 0.3 \mathrm{~mL}$ of $10 \% \mathrm{Al}\left(\mathrm{NO}_{3}\right)_{3}$ to the mixture and incubated for $10 \mathrm{~min}$ again followed by the addition of $4 \mathrm{ml}$ of $1 \mathrm{NaOH}$ and of methanol up to volume. After incubating for $30 \mathrm{~min}$ at room temperature for colour development, absorbance at $500 \mathrm{~nm}$ was measured. Total flavonoid was expressed as catichine equivalents [28] (Figure 2a).

\section{G. Determination of Total Carotenoid Contents}

The method of Lee and Velioglu [13, 27] was used for total carotenoid quantitations. In brief, $5 \mathrm{~g}$ of each sample and $50 \mathrm{ml}$ of $\mathrm{n}$-hexane-acetone-ethanol $(\mathrm{v} / \mathrm{v} ; 2: 1: 1)$ were placed in a flask, extracted on a shaker at $200 \mathrm{rpm}$ for 20 min at room temperature, centrifuged at $4000 \mathrm{rpm}$ for 10 min at $4{ }^{\circ} \mathrm{C}$, and the supernatants were collected and made up to $50 \mathrm{~mL}$ with extraction solvent. Two layers were observed after mixing the solvent, an organic (upper layer) and aqueous (lower layer). After carefully separating the layers, the absorbance was measured at $450 \mathrm{~nm}$. Total carotenoid was expressed as $\beta$-carotene equivalents.

\section{H. Determination of vitamin C Contents}

Procedures used to determine the vitamin $\mathrm{C}$ content were as described by Wright and Kader [32] for the determination of ascorbic acid by HPLC.

\section{Statistical Analysis}

All the experiments were conducted in three replicates and data obtained was analyzed statistically by one way ANOVA technique using Minitab Software. 


\section{RESULTS AND DISCUSSION}

\section{A. Physico-chemical analysis}

The physico-chemical parameters of the various varieties of durian fruit are presented in Table 1 . The $\mathrm{pH}$ values were ranged from 4.50-5.86. The durian fruit from D11 variety was found to be more acidic $(\mathrm{pH} 4.50)$ followed by Chaer Phoy ( $\mathrm{pH}$ 5.16), Yang Kang ( $\mathrm{pH}$ 5.52) and Ang Jin ( $\mathrm{pH}$ 5.86). Density and viscosity of all the fruit samples were in the range of $1.026-1.029 \mathrm{~g} / \mathrm{cm}^{3}$ and 1.044-1.127 $\mathrm{cP}$, respectively. Among all the durian varieties, Ang Jin variety offered highest values of total soluble solid contents (112.38 $\mathrm{g} / \mathrm{L})$ while, Yah Kang contained the lowest (103.15 g/L). Titrate-able acidity, measured at $25^{\circ} \mathrm{C}$, of all the durian samples was found to be analogous concentrations. Analysis of variance (ANOVA) revealed non-significant $(p>0.05)$ difference in the physico-chemical parameters of extract from various varieties of durian.

TABLE I. PHYSIO-CHEMICAL QUALITY PARAMETERS OF EXTRACT FROM VARIOUS VARIETIES OF DURIAN FRUIT

\begin{tabular}{lccccc}
\hline Varieties & $\mathrm{pH}$ & $\begin{array}{c}\text { Density } \\
\left(\mathrm{g} / \mathrm{cm}^{3}\right)\end{array}$ & Viscosity $(\mathrm{cP})$ & $\begin{array}{c}\text { TSS } \\
(\mathrm{g} / \mathrm{L})\end{array}$ & $\begin{array}{c}\mathrm{TA} \text { at } 25^{\circ} \mathrm{C} \\
(\mathrm{g} / \mathrm{L})\end{array}$ \\
\hline D11 & $4.50 \pm 0.04$ & $1.027 \pm 0.03$ & $1.129 \pm 0.04$ & $110.12 \pm 0.30$ & $3.710 \pm 0.15$ \\
Chaer Phoy & $5.16 \pm 0.08$ & $1.029 \pm 0.04$ & $1.036 \pm 0.01$ & $107.14 \pm 0.12$ & $3.620 \pm 0.12$ \\
Yah Kang & $5.52 \pm 0.10$ & $1.026 \pm 0.05$ & $1.027 \pm 0.02$ & $103.18 \pm 0.11$ & $3.530 \pm 0.14$ \\
Ang Jin & $5.86 \pm 0.14$ & $1.021 \pm 0.02$ & $1.101 \pm 0.04$ & $112.21 \pm 0.47$ & $3.411 \pm 0.11$ \\
\hline
\end{tabular}

\section{B. Antioxidant potentials}

\section{Total phenolics contents (TPC)}

The amount of total phenolics contents found in the durian samples varied widely among varieties. The values of TPC ranged from $690.62-998.29 \mathrm{mg} / \mathrm{L}$ as GAE (Fig. 2). The maximum TPC was found from the Ang Jin variety while the minimum from the Chaer Phoy variety. D11 and Yah Kang varieties of durian showed 730.46 and $825.37 \mathrm{mg} / \mathrm{L}$ TPC as GAE, respectively. Statistical analysis showed the significant $(p<0.05)$ variation in the TPC with respect to durian varieties.

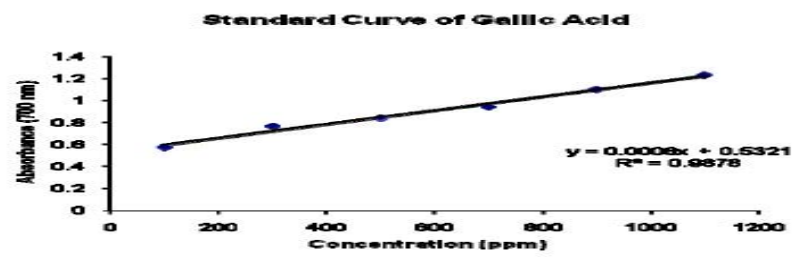

Figure 1. Standard curve of Gallic acid

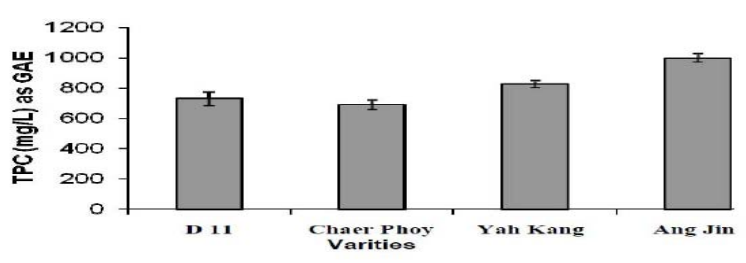

Figure 2. Total phenolic contents in different varieties of durian

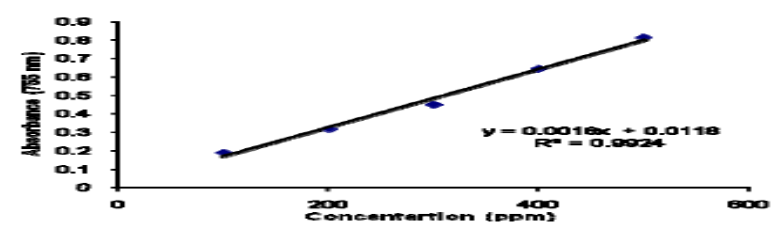

Figure 3. Standard curve of Catechine

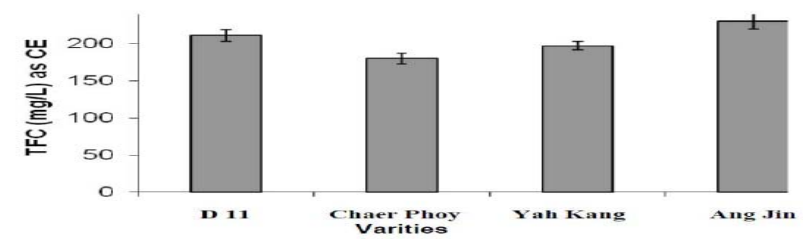

Figure 4. Total flavonoid contents in the different varieties of durian

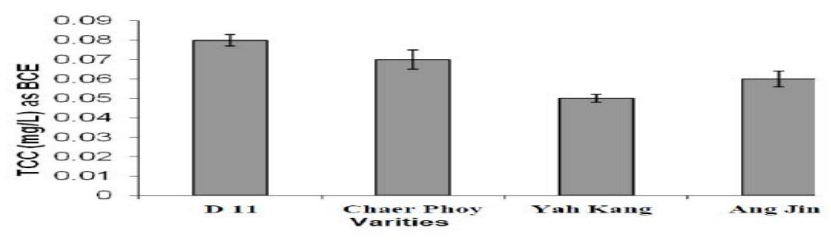

Figure 5. Total carotenoid contents in the different varieties of durian

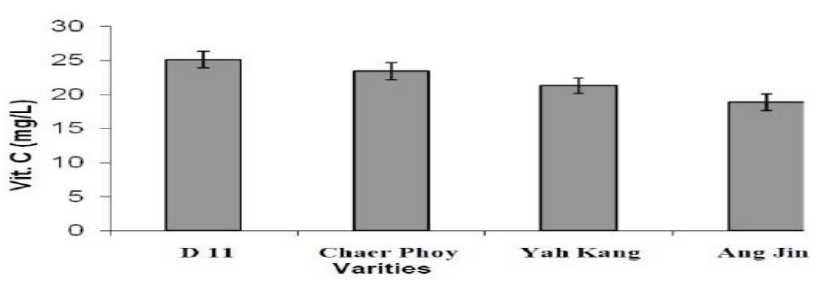

Figure 6. Estimation of vitamin C contents in the different varieties of durian

\section{Total flavonoid contents (TFC)}

The data regarding the TFC is presented in Fig. 4. it was observed that the amount of TFC found in the durian extract samples varied widely among varieties. The overall TFC found in samples of various varieties of durian were in the range of $211.36-220.34 \mathrm{mg} / \mathrm{L}$ as CE. The maximum TFC was found from the Ang Jin variety while the minimum from the D11 variety. Chaer Phoy and Yah Kang varieties of durian showed 219.27 and $216.61 \mathrm{mg} / \mathrm{L}$ TFC as CE, respectively. Statistical analysis showed that variations in TFC with respect to citrus varieties were non-significant $(\mathrm{p}>$ $0.05)$.

\section{E. Total Carotenoides Contents (TCC)}

The carotenoides contents were found in extract samples of various varieties of durian in very low concentration (Fig. 5 ). The overall range of carotenoides contents were 0.05 $0.08 \mathrm{mg} / \mathrm{L}$ measured as beta Carotene Equivalent although, the statistical analysis showed the significant $(p<0.05)$ variation in TCC with respect to durian varieties.

\section{F. Vitamin C Contents}

The amount of vitamin $\mathrm{C}$ found in the durian extract samples varied widely among varieties (Fig. 6). The concentration of vitamin $\mathrm{C}$ was found maximum in D11 variety $(25.13 \mathrm{mg} / \mathrm{L})$ and that of least in Ang Jin $(18.87 \mathrm{mg} / \mathrm{L})$. Based on these findings, the order of vitamin $\mathrm{C}$ contents in various varieties of durian was as follows; D11 > Chaer Phoy > Yah Kang > Ang Jin. Statistical analysis showed the significant $(p<0.05)$ variation in vitamin $\mathrm{C}$ with respect to durian varieties.

In nature, there are a number of various types of antioxidant compounds that play an important as radical scavengers, inhibit lipid peroxidation and other free radicalmediated processes and able to protect the human body as well as processed foods from oxidative damage ascribed to 
the reaction of free radicals. The uses of plant-based antioxidants like polyphenols, flavonoids, vitamin $\mathrm{C}$ are related to reduce the risk of incidence of coronary heart diseases, neurological disorders, and certain type of cancers [33-34]. The ability of fruit juices to exhibit antioxidant potential was closely related to their total phenolic and total flavonoids contents. This is because the phenolic compounds have the ability to donate hydrogen atoms from hydroxyl groups on their ring structures [35]. There are few reports in literature on the antioxidant potentials of fruits [36-38].

All the samples analyzed in the present study contained considerable amount of total phenolics, total flavonoids as well as good concentration of vitamin C. As reported earlier vitamin $\mathrm{C}$ is the major antioxidant present in fruits. This is expected as AA generally provides minor contribution to the antioxidants in fruits [38-40]. The contents of antioxidant phytochemicals varied among species, cultivars, varieties and geographical origins [41].

Mature durian sample showed the highest antiproliferative activity. This can be explained not only by relatively high antioxidant activity, but by the amount of flavonoids and other bioactive compounds. The results on cell proliferation can be explained as a synergistic effect of flavonoids, flavanols and ascorbic acid in mature durian. ${ }^{42}$ Our data correspond with that combinations of flavonoids, which are naturally present in whole fruits and vegetables, are more effective in cancer cell growth inhibition than the individual flavonoids. Durian can be used as a potential source of high-value phytochemicals with nutraceutical and functional food additive applications.

\section{CONCLUSION}

Malaysia has a great diversity of underutilized fruits that vary in appearance and organoleptic characteristics. There are great variations among different varieties of durian with respect to the content of antioxidant phytochemicals and quality attributes. Durian have high potential to be sources of antioxidants. The correlation results indicated that along with phenolic compounds, other antioxidant components such as vitamins $\mathrm{C}$ and $\mathrm{E}$ and carotenoids could also contribute to the antioxidant capacity of underutilized fruits. Bush variety contained significantly higher amounts of total phenolics and total flavonoids. While vitamin $\mathrm{C}$ contributed considerably to the Lisbon variety. It is thus recommended to consume durian fruit for uptake of antioxidant phytochemicals and vitamin C. Overall, findings of this study support the recommendation of many national dietary guidelines which encourages eating a variety of fruits every day, especially the durian. Efforts to promote their consumption should be continued for public health benefits. This antioxidant data would be valuable for epidemiological research and providing support for dietary guidelines.

\section{ACKNOWLEDGMENT}

The work reported in this paper was carried out in Analytical Laboratory, Department of Chemistry, University of Malaya, Kuala Lumpur, Malaysia through UM Research
Grant vide no. PS355/2009C. Thanks also to the Ministry of Higher Education Malaysia (MOHE) for financial support.

\section{REFERENCES}

[1] Voon, Y. Y. Hamid, N. S. A. Rusul, G. Osman, A. \& Quek, S. Y. 2007a. Food Chemistry, 103:7-1227.

[2] Voon, Y. Y. Hamid, N. S. A. G. Rusul, A. Osman and S.Y. Quek, Postharvest Biol. Technol., 46, 6-85 (2007b).

[3] R.J. Robbins, J. Agric. Food chem., 51, 2866-2887 (2003).

[4] R.J. Robbins, and S.R. Bean, J. Chromatography A., 1038, 97105(2004).

[5] L.W. Morton, R.A.A. Caccetta, I.B. Puddey, and K.D.Croft, Clin. Exp. Pharmaco. Physi., 27, 152-159 (2000).

[6] Y.C.Wang, Y.C. Chuang, and Y.H. ku, Taiwan. Food Chem., 102, 1163-1171 (2007).

[7] E.Belajova, and M. Suhaj, Food Chem., 86, 339-343 (2003).

[8] [8] J. Vanamala, L. Reddivari, K.S. Yoo, L.M. Pike, and B.S.Patil, J. Food Comp. and Anal., 19, 157-166(2006).

[9] P. Dugo, M.L. Presti, M. Ohman, A. Fazio, G. Dugo, and L.Mondello, J. Separ. Sci, 28, 1149-1156 (2005).

[10] Leuzzi, U. Caristi, C. Panzera, P. \& Licandro, G. 2000. Journal of Agriculture anf Food Chemistry, 48: 5501- 5506.

[11] Bocco, A. Cuvelier, M. E. Richard, H. \& Berset, C. 1998. Journal of Agricuture and Food Chemistry, 46: 2123-2129.

[12] Gil-Izquierdo, A. Gil, M. I. \& Ferreres, F. 2002. Journal of Agricture Food Chemistry, 50: 5107-5114.

[13] Lee, H. S. \& Castle, W. S. 2001. Journal of Agriculture Food Chemistry. 49: 877-882.

[14] Arancibia-Avila, P. Toledo, F. Park, Y. S. Jung, S. T. Kang, S. G. \& Heo, B. G. 2008. Food Science and Technology, 41: 2118-2125.

[15] Leontowicz, H. Leontowicz, M. Haruenkit, R. Poovarodom, S. Jastrzebski, Z. \& Drzewiecki, J. 2008. Journal of Food and Chemical Toxicology, 486: 581-589.

[16] Toledo, F. Arancibia-Avila, P. Park, Y. S. Jung, S. T. Kang, S. G. \& Heo, B. G. 2008. International Journal of Food Science and Nutrition. 59: 415-427.

[17] Chansiripornchai, N. Chansiripornchai, P. \& Pongsamart, S. 2008. Acta Horticulture, 786: 57-60.

[18] Daniel, R. S. Aziz, I. Than, W. \& Thomas, W. M. S. 2008. Asia Pacific Journal of Clinical Nutrition. $17: 35-39$.

[19] Siondalski, P. \& Lysiak-Szydlowska, W. 2007. Chemical and functional properties of food components, Boca Raton, FL: CRC Press LLC, Vol.3, pp. 439-450.

[20] Phutdhawong, W. Kaewkong, S. \& Buddhasukh, D. 2005. Malaysian Journal of Science. $32: 169-172$.

[21] Yaacob, O. \& Subhadrabandhu, S. 1995. The production of economic fruits in South-East Asia, Oxford University Press, Kuala Lumpur.

[22] Weenen, H. Koolhaas, W. E. \& Apriyantono, A. 1996. Journal of Agricultural Food Chemistry, $44: 3291-3293$.

[23] AOAC, Official Methods of Analysis. 15th Edn., Association of Official Analytical

[24] Chemists, 1990.Washington, DC., USA., pp. 200-210.

[25] Moreno, C. S. Cano, M. P. de Ancos, B. Plaza, L. Olmedilla, B. Granado, F. \& Martín, A. 2003. American Journal of Clinical Nutrition. $78: 454-460$.

[26] Liu, M. Li, X. Q. Weber, C. Lee, C. Y. Brown, J. \& Liu, R. H. 2002. Journal of Agriculture Food Chemistry, $50:$ 2926-2930.

[27] Isabelle, M. Lee, B. L. Lim, M. T. Koh, W. P. Huang, D. \& Ong, C. N. 2010. Food Chemistry. 123,

$77-84$

[28] Velioglu, Y. S. Mazza, G. Gao, L. \& Oomah, B. D. 2004. Journal of Agricultural Food Chemistry, 46: 4113-4117.

[29] Singleton, V. L. Orthofer, R. \& Lamuela-Raventos, R. M. 1999. Methods Enzymology. 299: 152-178.

[30] Heimler, D. Vignolini, P. Dini, M. G. Vincieri, F. F. \& Romani, A. 2006. Food Chemistry, 99:464-469.

[31] Park, Y. S. Jung, S. T. Kang, S. G. Drzewiecki, J. Namiesnik, J. \& Haruenkit, R. 2006. International Journal of Food Science and Nutrition. 57: 107-122.

[32] Sultana, B. Anwar, F. Asi, M. R. \& Chatha, S. A. S. 2008. Grasas Aceites.59: 205-217. 
[33] Wright, K. P. Kader, A. A. \& Psatharu, A. 1997. Biological Technology. 10: 39-48.

[34] Gardner, P. T. White, T. A. C. Mcphailand, D. B. \& Duthie, G. G. 2000. Food Chemistry, 68: 471-474.

[35] Hussain, A. I. Anwar, F. Sheraziand, S. T. H. \& Przybylski, R. 2008. Food Chemistry. 108: 986-995.

[36] Scott, G. 1977. Chichester, Albion Publishing, England.

[37] Hainida, E. Ikram, K. Eng, K. H. Jalil, A. M. M. Ismail, M. Idris, S. Azlan, A. Nazri, H. S. M. Diton, N. A. M. \& Mokhtar, R. A. M. 2009 Journal of Food Components and Analysis. 22: 388-393.

[38] Cheng, G. W. \& Breen, P. J. 1991. Journal of American Society of Horticulture Science.116: 865-869.

[39] Vinson, J. A. Su, X. Zubic, L. \& Bose, P. 2001. Journal of Agriculture Food Chemistry. 49: 5315-5321.

[40] Rice-Evanand, C. A. \& Miller, N. 1996. Journal of Biochemical Society Transactions. 24: 790-800.

[41] Marin, F. R. Martinez, M. Uribesalgo, T. Castillo, S. \& Frutos, M. 2002. Food Chemistry. 78:319-324.

[42] Chun, O. K. Kim, D. O. Smith, N. Schroeder, D. Hanand, J. T \& Lee, C. Y. 2005. Journal of Science Food Agriculture, 85:1715-1724.
[43] Campbell, J. K. King, J. L. Harmston, M. Lila, M. A. \& Erdman J. W. 2006. Journal of Food Science, 71: S358-S363.

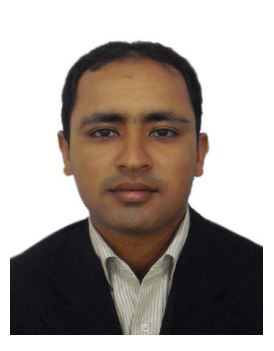

Muhammad Aqeel Ashraf is born on 11th of Janury 1983 in a small village of Khanewal District in Punjab province, Pakistan. He got his BSc degree from, The Islmia Postgraduate College Khanewal, Pakistan in 2002. He got his M.Sc Chemistry degree from Bahauddin Zakariya University Multan, Pakistan in 2005. He got his M.Phil Chemistry degree from, The Islamia University of Bahawalpur, Pakistan in 2009. Later he got scholarship from Ministry of Higher Education (MoHE) Malaysia in the year 2009 to complete his $\mathrm{PhD}$ Degree at University of Malaya, Kaula Lumpur, Malaysia. Currently he is working on $\mathrm{PhD}$ project entitled "Chemical speciation \& bioavailability of heavy metals in the former tin mining catchment Bestari Jaya, Peninsular Malaysia". He has more then 12 research publications in well reputed ISI indexed journals. He has represented his research work in more then 15 national \& international conferences. He is member of different national \& international organizations including WWF, IUPAC \& Chemical Society of Pakistan. 